
and Macit Koldas

\title{
An evaluation of biomarkers indicating endothelial cell damage, inflammation and coagulation in children with Henoch-Schönlein purpura Henoch-Schönlein Purpura'lı çocuklarda endotel disfonksiyonu, inflamasyon ve koagülasyon biyobelirteçlerinin değerlendirilmesi
}

https://doi.org/10.1515/tjb-2018-0127

Received April 3, 2018; accepted May 17, 2019; previously published online October 12, 2019

\section{Abstract}

Objective: Henoch-Schönlein purpura (HSP) is characterized by generalized vasculitis. The etiopathogenesis of the disease is unknown, but inflammation and endothelial dysfunction have been held responsible. Therefore, herein we investigated serum levels of biomarkers indicating endothelial cell damage, inflammation and coagulation in children with HSP.

Materials and methods: Twenty six patients with HSP and 26 healthy children were included in the study. Routine biochemical tests and laboratory parameters showing inflammation, coagulation, and endothelial cell damage were examined in all subjects.

Results: White blood cell (WBC) number, C-reactive protein (CRP) level, erythrocyte sedimentation rate (ESR), neutrophil/lymphocyte rate (NLR), triglyceride, immunoglobulin $\mathrm{A}(\mathrm{IgA})$, and $\mathrm{C}_{3}$ were significantly higher in children with HSP than the controls. HDL and albumin levels were lower in the patients with HSP. Endocan levels were not significantly different between the HSP and control

\footnotetext{
*Corresponding author: Nilgun Selcuk Duru, University of Health Sciences, Haseki Training and Research Hospital, Department of Pediatrics, Istanbul, Turkey, e-mail: nilgunduru@yahoo.com. https://orcid.org/0000-0001-9105-0529

Kamil Sahin, Ala Üstyol and Murat Elevli: University of Health Sciences, Haseki Training and Research Hospital, Department of Pediatrics, Istanbul, Turkey, e-mail: drkamil_sahin@hotmail.com (K. Sahin); alaustyol@gmail.com (A. Üstyol); muratelevli@gmail.com (M. Elevli). https://orcid.org/0000-0002-0443-2148 (K. Sahin) Cihan Coskun and Macit Koldas: University of Health Sciences, Haseki Training and Research Hospital, Department of Biochemistry, Istanbul, Turkey, e-mail: kuzeycihan2012@gmail.com (C. Coskun); macitkoldas@gmail.com (M. Koldas). https://orcid.org/0000-00018288-8741 (C. Coskun)
}

groups $(\mathrm{p}=0.884)$. Serum endocan levels in patients with HSP were inversely correlated only with activated partial thromboplastin time (APTT) $(r=-0.485, \mathrm{p}=0.012)$.

Conclusion: Coagulation abnormalities and increased acute phase reactants were present in patients with HSP while no difference was determined in endocan levels.

Keywords: D-dimer; Endocan; Endothelial dysfunction; Inflammation; Henoch-Schönlein purpura.

Öz

Amaç: Henoch-Schönlein purpurası (HSP) jeneralize vaskülit ile karakterizedir. Hastalığın etiyopatogenezi bilinmemekte olup inflamasyon ve endotelyal disfonksiyon sorumlu tutulmaktadır. Bu nedenle çalışmamızda HSP’li çocuklarda endotel hücre hasarı, inflamasyon ve pihtılaşmayı belirten bazı biyobelirteçlerin serum düzeyleri araştırılmıştır.

Gereç ve Yöntem: Çalışmaya HSP'li 26 hasta ve kontrol grubu olarak 26 sağlıklı çocuk dahil edildi. Tüm olgularda rutin biyokimyasal testler ve inflamasyon, koagülasyon ve endotel hücre hasarını gösteren laboratuvar verileri analiz edildi.

Bulgular: HSP'li çocuklarda beyaz kan hücresi (WBC) sayıs1, C-reaktif protein (CRP) düzeyi, eritrosit sedimentasyon hızı (ESH), nötrofil/lenfosit (NLR) oranı, trigliserit, immünoglobulin A (IgA) ve C3 kontrol grubundan anlamlı olarak yüksek bulundu. HDL ve albümin düzeyleri ise HSP’li hastalarda daha düşüktü. Endocan düzeyleri açısindan gruplar arasinda anlamlı farklılık saptanmadı $(p=0.884)$. Serum endokan düzeyleri sadece aktive parsiyel tromboplastin zamanı (APTT) ile ters korele bulundu $(\mathrm{r}=-0.485, \mathrm{p}=0.012)$.

Sonuç: HSP'li çocuklarda koagülasyon anormallikleri ve artmış akut faz reaktanları gözlenirken, bir endotel disfonksiyon belirteci olan endokan düzeylerinde anlamlı farklılık saptanmadi. 
Anahtar Kelimeler: D-dimer; endoksan; endotel disfonksiyonu; inflamasyon; Henoch-Schönlein purpurası.

\section{Introduction}

Henoch-Schönlein purpura (HSP) is one of the most common vasculitic syndromes. The clinical manifestation is variable and characterized by non-thrombocytopenic cutaneous palpable purpura, joint manifestations, gastrointestinal (GI) findings, and hematuria/proteinuria [1]. The disease is usually self-limiting, but can rarely cause severe renal disease. Although HSP has been known for many years, the etiopathogenesis is not still clear. However, it has been proposed that vascular inflammation and endothelial dysfunction may play an important role in the pathogenesis [2-4].

HSP is an immune-mediated inflammatory disease. IgA deposition in vessel walls leads to endothelial cell damage and cytokines secretion [1]. The coagulation system and fibrinolysis are thus activated. Several studies have reported biochemical markers indicating endothelial cell damage or hemostatic parameters in HSP patients [5-10].

Endocan is excreted from vascular endothelial cells, renal distal tubule cells, and bronchi [11-13]. Endocan has recently been investigated in various pathological processes, such as cancer, infections and rheumatological diseases [11-15]. Tumor necrosis factor alpha (TNF- $\alpha$ ) and vascular endothelial growth factor (VEGF) stimulate endocan expression and secretion from endothelial cells [13]. Increased levels of both have been observed in patients with HSP $[10,16]$. We therefore presumed that endocan may be a vascular endothelium damage biomarker for HSP.

Our aim in this study was to investigate various inflammation and coagulation parameters and endocan as endothelial dysfunction markers in children with HSP and to compare these with healthy children. We also examined the relationship between endocan and clinical findings and laboratory tests in patients with HSP.

\section{Materials and methods}

\section{Patient selection}

This case-control study was performed in the pediatric clinic of our hospital between February, 2016, and January, 2017. The study included 26 patients (mean age $7.4 \pm 3.3$ years) with HSP and 26 healthy children (mean age $6.7 \pm 2.8$ years) as a control group. Diagnosis of HSP was based on European League against Rheumatism/Pediatric Rheumatology European Society (EULAR/PRES) classification criteria for HSP [17]. HSP was diagnosed in patients with non-thrombocytopenic palpable purpura as mandatory criterion and in the presence of at least one of diffuse abdominal pain, any biopsy showing IgA deposition, joint findings or renal involvement. Patients' clinical characteristics (age, gender and clinical course) are summarized in Table 1.

Patients with other forms of systemic vasculitis, diabetes mellitus, hypertension, thyroid dysfunction, hematological disorders, known malignancy, infection, liver or kidney disease were not taken into the study. The control

Table 1: Demographic features and clinical findings in patients with HSP and control subjects.

\begin{tabular}{|c|c|c|c|c|c|}
\hline \multirow[t]{2}{*}{ Parameters } & \multicolumn{2}{|c|}{$\operatorname{HSP}(n=26)$} & \multicolumn{2}{|r|}{$\begin{array}{r}\text { Controls } \\
(n=26)\end{array}$} & \multirow[t]{2}{*}{ p-Value } \\
\hline & n & $\%$ & n & $\%$ & \\
\hline \multicolumn{6}{|l|}{ Gender } \\
\hline Male & 14 & 53.8 & 16 & 61.5 & $0.575^{\mathrm{a}}$ \\
\hline \multirow[t]{2}{*}{ Female } & 12 & 46.2 & 10 & 38.5 & \\
\hline & \multicolumn{2}{|c|}{$\begin{array}{r}\text { Median } \\
(\min -\max )\end{array}$} & \multicolumn{2}{|c|}{$\begin{array}{r}\text { Median } \\
(\min -\max )\end{array}$} & \\
\hline \multicolumn{6}{|l|}{ Age } \\
\hline Years & & $(2-17)$ & & $7(2-13)$ & $0.555^{b}$ \\
\hline \multicolumn{6}{|l|}{ Season } \\
\hline Spring & 3 & 11.5 & & & \\
\hline Summer & 7 & 26.9 & & & \\
\hline Fall & 9 & 34.6 & & & \\
\hline Winter & 7 & 26.9 & & & \\
\hline \multicolumn{6}{|c|}{ Clinical findings rash } \\
\hline Absent & 0 & 0.0 & & & \\
\hline Present & 26 & 100.0 & & & \\
\hline \multicolumn{6}{|c|}{ Arthralgia/arthritis } \\
\hline Absent & 17 & 65.4 & & & \\
\hline Present & 9 & 34.6 & & & \\
\hline \multicolumn{6}{|c|}{ GI manifestations } \\
\hline Absent & 5 & 19.2 & & & \\
\hline \multicolumn{6}{|c|}{ Abdominal pain } \\
\hline Present & 12 & 46.2 & & & \\
\hline \multicolumn{6}{|l|}{ GI bleeding } \\
\hline Present & 9 & 34.6 & & & \\
\hline \multicolumn{6}{|c|}{ Renal involvement } \\
\hline Absent & 20 & 76.9 & & & \\
\hline Present & 6 & 23.1 & & & \\
\hline \multicolumn{6}{|l|}{ Other } \\
\hline Present & 2 & 7.7 & & & \\
\hline \multicolumn{6}{|l|}{ Treatment } \\
\hline NSAID & 20 & 76.9 & & & \\
\hline Steroid & 11 & 42.3 & & & \\
\hline
\end{tabular}

HSP, Henoch-Schönlein purpura; Min, minimum; Max, maximum; GI, gastrointestinal; NSAID, nonsteroidal anti-inflammatory drug. ${ }^{a} \chi^{2}$ test, ${ }^{\mathrm{b}}$ Mann-Whitney U test. 
group was selected from patients with no known acute or chronic disease attending our pediatric clinic for other reasons. The study was accordance with the Helsinki Declaration. It was approved by the local Ethics Committee (Approval No. 03/02/2016-328). All participants provided written informed consent.

Renal involvement was defined as the presence of any hematuria and/or proteinuria. Arthralgia or arthritis were determined as joint manifestations. GI manifestations were diffuse abdominal pain and/or GI bleeding, or a positive test for occult blood in faeces.

\section{Biochemical analysis}

Blood samples were collected (without stasis after morning fasting) from all participants and placed into tubes with gel, and tubes containing K2EDTA (Becton Dickinson, UK) on the first day of admission. Serum samples placed into tubes with gel were allowed to clot before centrifugation. Following centrifugation for $10 \mathrm{~min}$ at $1000 \mathrm{~g}$, the serum was aliquoted and kept at $-70^{\circ} \mathrm{C}$ until the day of study.

Compete blood count parameter analysis was performed using the Sysmex XE-2100 hematology system (TOA Medical Electronics, Kobe, Japan). The neutrophil/ lymphocyte ratio (NLR) was calculated as a ratio between absolute neutrophil and absolute lymphocyte counts. Serum C-reactive protein (CRP) levels, immunoglobulin and complements (C3, C4) were measured using an immune turbidimetric method with an AU-2700 autoanalyzer (Beckman Coulter, USA). Other biochemical tests were determined using a spectrophotometric method with an AU-2700 autoanalyzer (Beckman Coulter, USA). Blood samples for coagulation tests were provided using 3.2\% concentration citrate anticoagulant. Plasma was prepared shortly after blood collection by centrifugation at $1000 \mathrm{~g}$ for $10 \mathrm{~min}$, and was then tested. Coagulation tests were measured by chromogenic assay using the ACL TOP 500 autoanalyzer (Beckman/Instrumentation Laboratory). Stool occult blood was assessed using the immunochromatographic rapid test (Standard Diagnostics Inc., South Korea). After centrifugation for $5 \mathrm{~min}$ at $600 \mathrm{~g}$, urine samples were tested using a Urised II \& Labumat II autoanalyzer (77 ElektronikaKft, Budapest, Hungary).

\section{Human endocan measurements}

Endocan concentrations were evaluated with the sandwich enzyme-linked immunosorbent assay (ELISA) method. The manufacturer's recommendations were properly applied for tests. Evaluations were performed using a Bio-tek Synergy HT (BioTek Instrument Inc., Winooski, VT, USA) ELISA plate reader. The results were expressed as $\mathrm{pg} / \mathrm{mL}$. The reference range of serum endocan was 15.63 to $1000 \mathrm{pg} / \mathrm{mL}$. The coefficients of variation were $10 \%$ and $12 \%$ for intra- and inter-assay precision, respectively. The lower limit of detection for endocan was $6.9 \mathrm{pg} / \mathrm{mL}$.

\section{Statistical analysis}

Statistical analysis was carried out on SPSS 15.0 software. Numbers and percentages were used to express categorical variables, and mean and standard deviation or median (minimum-maximum) were used for numerical variables. The Kolmogorov-Smirnov and Shapiro-Wilk tests were used to determine the normal distribution. The Mann-Whitney $\mathrm{U}$ test or Student $\mathrm{t}$ test were for comparisons between two groups, depending on the sample distribution. Comparisons between more than two groups were carried out using the Kruskal-Wallis test again depending on the sample distribution. Multivariate logistic regression analysis was performed to determine odds ratio at $95 \%$ confidence interval (CI). Categorical variables were compared using the $\chi^{2}$ test. Monte Carlo simulation was performed in boundary conditions. Pearson and Spearman correlation analysis were used to evaluate relations between variables. $p<0.05$ was regarded as the alpha $(\alpha)$ significance level.

\section{Results}

\section{Patient characteristics}

The mean age of the patients was $7.4 \pm 3.3$ years, and the mean age of the controls $6.7 \pm 2.8$ years. The difference was not statistically significant $(\mathrm{p}=0.555)$. The HSP group consisted of 14 boys (53.8\%) and 12 girls (46.2\%), and the control group of 16 boys (61.5\%) and 10 girls (38.5\%). Sex distributions were similar between the groups $(\mathrm{p}=0.575)$. Disease onset occurred in all seasons, but with the highest incidence being reported during the fall (34.6\%). The second highest incidence was observed during summer and winter (26.9\%) (Table 1).

\section{Clinical manifestations}

Of the children with HSP, rash was present in 26 (100\%), arthralgia/arthritis in 9 (34.6\%), abdominal pain and GI 
bleeding in 9 (34.6\%), abdominal pain only in $12(46.2 \%)$, renal findings in 6 (23.1\%). Twenty children were treated with non-steroidal anti-inflammatory drugs and 11 received steroids. Participants' clinical characteristics are presented in Table 1.

\section{Laboratory tests}

Following laboratory evaluation, significant mean erythrocyte sedimentation rate (ESR) $(p=0.030), \operatorname{CRP}(p=0.001)$, white blood cell (WBC) $(p=0.025)$, NLR $(p=0.02)$, D-dimer $(p<0.001)$, triglyceride $(p=0.043)$, globulin $(p=0.014)$, IgA $(\mathrm{p}=0.001)$, and $\mathrm{C}_{3}(\mathrm{p}<0.001)$ value elevations were determined in the patients compared to the healthy controls. Mean HDL and albumin values were significantly lower in the patients than in the healthy controls. Patients' mean endocan levels were $809.4 \pm 430.4 \mathrm{pg} / \mathrm{mL}$, and were similar to those of the control group $(775.6 \pm 374.1 \mathrm{pg} / \mathrm{mL}$; $\mathrm{p}=0.884)$. Differences in other parameters between the groups were not significant. The results of these comparisons are given in Table 2.

The receiver operating characteristic (ROC) curves for biochemical parameters are shown in Figure 1. The areas under the curve of D-dimer, NLR, IgA and C3 were 0.94, 0.74, 0.74 and 0.89, respectively. Our multivariate analysis, increased IgA, NLR, CRP, C3, D-dimer levels, and decreased albumin level were not related to HSP (Table 3). Serum endocan concentrations were inversely correlated with activated partial thromboplastin time (APTT) $(r=-0.485, p=0.012)$, but did not correlate with other parameters.

Table 2: Comparison of laboratory parameters between patients and controls.

\begin{tabular}{|c|c|c|c|}
\hline & Patients $(n=26)$ & Controls $(n=26)$ & p-Value \\
\hline Endocan $(\mathrm{pg} / \mathrm{mL}$ ) median (min-max) & $698(118-1867)$ & $717(236-1722)$ & $0.884^{\circ}$ \\
\hline $\mathrm{CRP}(\mathrm{mg} / \mathrm{L})$ mean $\pm \mathrm{SD}$ & $8.5(0.0-34.2)$ & $0.7(0.1-19.3)$ & 0.001 \\
\hline $\mathrm{ESR}(\mathrm{mm} / \mathrm{h})$ mean $\pm \mathrm{SD}$ & $27 \pm 13$ & $20 \pm 8$ & 0.030 \\
\hline Leucocyte $\left(/ \mathrm{mm}^{3}\right)$ median (min-max) & $10,435 \pm 3410$ & $8430 \pm 2745$ & 0.025 \\
\hline Neutrophil/lymph, median (min-max) & $1.88(0.59-6.96)$ & $1.01(0.35-4.21)$ & $0.002^{\circ}$ \\
\hline $\mathrm{HCT}(\%)$ mean $\pm \mathrm{SD}$ & $35.5 \pm 2.7$ & $36.8 \pm 2.4$ & 0.067 \\
\hline $\mathrm{HB}(\mathrm{g} / \mathrm{L})$ mean $\pm \mathrm{SD}$ & $12.1 \pm 1.1$ & $12.6 \pm 0.7$ & 0.069 \\
\hline $\operatorname{PLT}\left(/ \mathrm{mm}^{3}\right)$ mean $\pm \mathrm{SD}$ & $344,384 \pm 64,670$ & $307,961 \pm 82,944$ & 0.084 \\
\hline $\mathrm{MPV}(\mathrm{fL})$ mean $\pm \mathrm{SD}$ & $9.6 \pm 0.8$ & $10.0 \pm 0.9$ & 0.121 \\
\hline PDW (\%) mean \pm SD & $10.9 \pm 1.6$ & $11.8 \pm 1.7$ & 0.076 \\
\hline $\mathrm{PTT}(\mathrm{s})$ mean $\pm \mathrm{SD}$ & $11.8 \pm 1.0$ & $11.7 \pm 0.7$ & 0.837 \\
\hline INR (s) mean \pm SD & $0.98 \pm 0.08$ & $0.99 \pm 0.06$ & 0.790 \\
\hline APTT (s) mean \pm SD & $25.1 \pm 3.3$ & $26.3 \pm 2.8$ & 0.150 \\
\hline Fibrinogen $(\mathrm{mg} / \mathrm{dL})$ mean $\pm \mathrm{SD}$ & $329 \pm 68$ & $307 \pm 69$ & 0.258 \\
\hline D-dimer ( $\mathrm{ng} / \mathrm{mL}$ ) median (min-max) & $1540(324-6960)$ & $280(92-635)$ & $<0.001^{2}$ \\
\hline Urea (mg/dL) median (min-max) & $24(12-47)$ & $21(11-37)$ & $0.134^{\circ}$ \\
\hline Creatinine $(\mathrm{mg} / \mathrm{dL})$ mean $\pm \mathrm{SD}$ & $0.38 \pm 0.12$ & $0.44 \pm 0.17$ & 0.336 \\
\hline Cholesterol (mg/dL) mean \pm SD & $150 \pm 23$ & $159 \pm 30$ & 0.282 \\
\hline Triglyceride (mg/dL) median (min-max) & $94(37-413)$ & $71(36-173)$ & 0.043 \\
\hline $\mathrm{LDL}(\mathrm{mg} / \mathrm{dL})$ mean $\pm \mathrm{SD}$ & $84 \pm 18$ & $89 \pm 24$ & 0.377 \\
\hline $\mathrm{HDL}(\mathrm{mg} / \mathrm{dL})$ mean $\pm \mathrm{SD}$ & $44 \pm 9$ & $53 \pm 13$ & 0.008 \\
\hline Albumin $(\mathrm{g} / \mathrm{dL})$ mean $\pm \mathrm{SD}$ & $3.97 \pm 0.33$ & $4.41 \pm 0.31$ & $<0.001$ \\
\hline Globulin $(\mathrm{g} / \mathrm{dL})$ mean $\pm \mathrm{SD}$ & $2.94 \pm 0.43$ & $2.64 \pm 0.42$ & 0.014 \\
\hline IgG (mg/dL) median (min-max) & $1002(545-1859)$ & $943(431-1564)$ & $0.142^{\circ}$ \\
\hline IgE (IU/mL) median (min-max) & $64(7-1133)$ & $65(4-862)$ & $0.585^{\circ}$ \\
\hline IgM (mg/dL) median (min-max) & $89(40-176)$ & $109(52-249)$ & $0.407^{\circ}$ \\
\hline $\operatorname{IgA}(\mathrm{mg} / \mathrm{dL})$ mean $\pm \mathrm{SD}$ & $169 \pm 59$ & $112 \pm 50$ & 0.001 \\
\hline $\mathrm{C} 3(\mathrm{mg} / \mathrm{dL})$ mean $\pm \mathrm{SD}$ & $148 \pm 15$ & $123 \pm 15$ & $<0.001$ \\
\hline $\mathrm{C} 4(\mathrm{mg} / \mathrm{dL})$ median (min-max) & $31(8-234)$ & $29(10-44)$ & $0.095^{\circ}$ \\
\hline
\end{tabular}

CRP, C-reactive protein; ESR, erythrocyte sedimentation rate; $\mathrm{HCT}$, hematocrit; $\mathrm{HB}$, hemoglobin; PLT, platelet; MPV, mean platelet volume; PDW, platelet distribution width; PTT, prothrombin time; INR, international normalized ratio; APTT, activated partial thromboplastin time; LDL, low-density lipoprotein; HDL, high-density lipoprotein; Ig, Immunoglobulin; C, complement. All variables are showed as mean \pm SD (Standard Deviation) or median (minimum-maximum) for continuous data with or without a normal distribution, respectively. ${ }^{a}$ MannWhitney $\mathrm{U}$ test. All other Student $t$ test. Bold values indicate statistical significance at the $p<0.05$ level. 

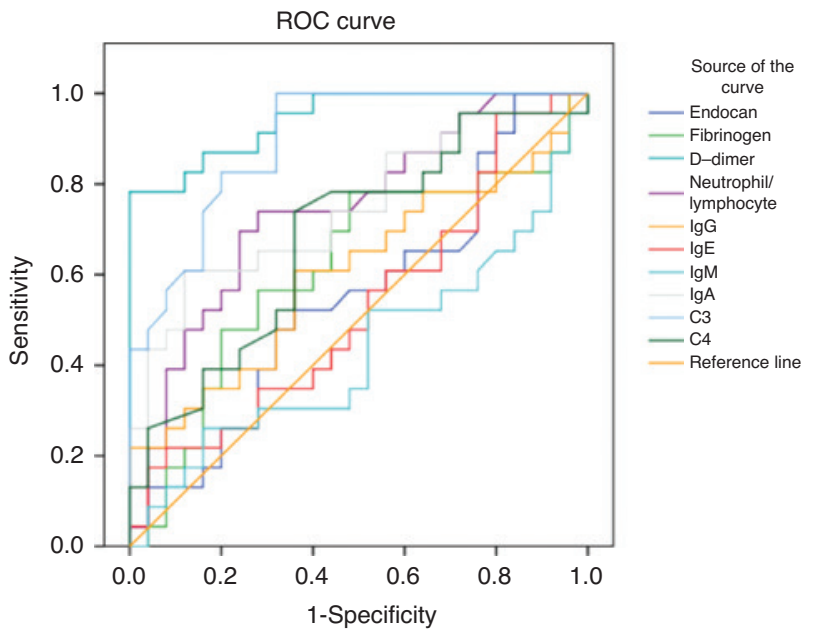

Area under the curve

\begin{tabular}{lrrrrr}
\hline $\begin{array}{l}\text { Test result } \\
\text { variable(s) }\end{array}$ & Area & SE & p-Value & $\begin{array}{r}95 \% \text { Confidence } \\
\text { interval }\end{array}$ \\
\hline Endocan & 0.550 & 0.084 & 0.556 & 0.384 & 0.715 \\
Fibrinogen & 0.616 & 0.084 & 0.170 & 0.451 & 0.781 \\
D-dimer & $\mathbf{0 . 9 4 4}$ & 0.030 & $<0.001$ & 0.886 & 1.003 \\
Neutrophil/ & $\mathbf{0 . 7 4 3}$ & 0.072 & 0.004 & 0.602 & 0.884 \\
lymphocyte & & & & & \\
IgG & 0.603 & 0.084 & 0.219 & 0.440 & 0.767 \\
IgE & 0.529 & 0.085 & 0.733 & 0.363 & 0.695 \\
IgM & 0.432 & 0.085 & 0.421 & 0.265 & 0.599 \\
IgA & $\mathbf{0 . 7 4 6}$ & 0.073 & 0.003 & 0.604 & 0.888 \\
C3 & $\mathbf{0 . 8 9 5}$ & 0.044 & $<0.001$ & 0.809 & 0.981 \\
C4 & 0.681 & 0.078 & 0.032 & 0.528 & 0.834 \\
\hline
\end{tabular}

Figure 1: Receiver-operating characteristic (ROC) curve of the RDW for predicting HSP Henoch-Schonlein purpura. Areas under the curve of D-dimer, NLR, IgA and C3 are indicated by bold values.

Table 3: Logistic regression analysis of some biomarkers.

\begin{tabular}{lrrr}
\hline Risk factor & p-Value & OR & 95\% Cl \\
\hline IgA increase & 0.422 & 1.097 & $0.875-1.375$ \\
NLR increase & 0.364 & 56.539 & $0.009-341257.247$ \\
CRP increase & 0.517 & 1.167 & $0.731-1.863$ \\
C3 increase & 0.583 & 0.925 & $0.702-1.220$ \\
D dimer increase & 0.393 & 1.041 & $0.950-1.141$ \\
Albumin decrease & 0.544 & 0.045 & $0.000-990.097$ \\
\hline
\end{tabular}

$\mathrm{Cl}$, Confidence interval; CRP, C-reactive protein; NLR, neutrophil/ lenfocyte rate; $\mathrm{OR}$, odds ratio.

No relation was determined between endocan and clinical findings in patients with HSP (Table 4).

\section{Discussion}

HSP is a small vessel vasculitis drew on by IgA-immune deposits, complement proteins and neutrophil infiltration
Table 4: Relationships between endocan and clinical findings in patients.

\begin{tabular}{|c|c|c|c|}
\hline & $\mathbf{n}$ & Endocan $(\mathrm{pg} / \mathrm{mL})$ & p-Value \\
\hline \multicolumn{4}{|l|}{ Gender } \\
\hline Male & 14 & $959 \pm 491$ & 0.046 \\
\hline Female & 12 & $634 \pm 271$ & \\
\hline \multicolumn{4}{|l|}{ Season } \\
\hline Spring & 3 & $814 \pm 206$ & $0.733^{\mathrm{a}}$ \\
\hline Summer & 7 & $810 \pm 616$ & \\
\hline Autumn & 9 & $709 \pm 265$ & \\
\hline Winter & 7 & $934 \pm 500$ & \\
\hline \multicolumn{4}{|c|}{ Clinical findings rash } \\
\hline Present & 26 & $807 \pm 405$ & \\
\hline \multicolumn{4}{|c|}{ Arthralgia/arthritis } \\
\hline Absent & 17 & $813 \pm 500$ & 0.975 \\
\hline Present & 9 & $690 \pm 518$ & \\
\hline \multicolumn{4}{|c|}{ Abdominal pain } \\
\hline Absent & 5 & $812 \pm 445$ & $0.649^{a}$ \\
\hline \multicolumn{4}{|c|}{ Abdominal pain without GI bleeding } \\
\hline Present & 12 & $856 \pm 412$ & \\
\hline \multicolumn{4}{|c|}{ Abdominal pain with GI bleeding } \\
\hline Present & 9 & $752 \pm 368$ & \\
\hline \multicolumn{4}{|l|}{ Renal } \\
\hline Absent & 20 & $1000 \pm 595$ & 0.223 \\
\hline Present & 6 & $765 \pm 409$ & \\
\hline \multicolumn{4}{|c|}{ Treatment NSAi } \\
\hline Absent & 6 & $629 \pm 380$ & 0.251 \\
\hline Present & 20 & $863 \pm 438$ & \\
\hline \multicolumn{4}{|l|}{ Steroid } \\
\hline Absent & 15 & $738 \pm 362$ & 0.339 \\
\hline Present & 11 & $905 \pm 511$ & \\
\hline \multicolumn{4}{|c|}{ Urine analysis } \\
\hline Normal & 20 & $753 \pm 339$ & 0.710 \\
\hline \multicolumn{4}{|c|}{$>5$ Erythrocyte hematuria } \\
\hline Present & 6 & $808 \pm 525$ & \\
\hline \multicolumn{4}{|c|}{ Fetal occult blood } \\
\hline Negative & 17 & $807 \pm 436$ & 0.979 \\
\hline Positive & 9 & $812 \pm 445$ & \\
\hline
\end{tabular}

[2]. IgA is the most important component of the immune deposits in HSP. IgA is able to activate complements by inducing the alternative complement pathways and mannan-binding lectin. It is also capable of binding to some receptors, the most important of which is FcoRI, which is capable of inducing pro-inflammatory reactions such as phagocytosis, neutrophil migration, formation of reactive oxygen species (ROS), cytokine secretion and the release of neutrophil extracellular traps [2]. Proinflammatory factors, such as TNF- $\alpha$, interleukin-1, interleukin-6, transforming growth factor (TGF)-b, VEGF, and 
chemokines are secreted as a result of inflammation and endothelial cell damage in HSP $[8,10,16,18]$.

Studies have shown high D-dimer levels in patients with HSP $[5,9]$. Hyperfibrinolysis secondary to endothelial damage has also been reported in patients with HSP [10]. Activation of inflammation causes the coagulation system to be activated. There are two suppositions on this subject; the one of them is that the circulating immune complexes act on the endothelial cells, and plasminogen proactivators are secreted. The other supposition is that proteolytic enzymes are secreted from inflammatory tissue cells, and these increase D-dimers [5, 19].

This study measured various biomarkers in patients with HSP and healthy controls - inflammatory factors as CRP, ESR, WBC, NLR, albumin and globulin, immunological markers including IgA, IgM, IgEand IgG, vascular permeability-related biomarkers such as $\mathrm{C} 3$ and $\mathrm{C} 4$, coagulation parameters including platelets, MPV, PDW, PT, APTT, D-dimer and fibrinogen, and endothelial dysfunction markers such as endocan and lipid profiles, and also performed other routine tests such as urea and Hb. CRP, ESR, WBC, NLR, globulin, C3 and IgA values were significantly higher, while albumin values were lower in patients with HSP than in the controls. CRP, ESR and WBC are non-specific markers of inflammatory activity. Previous studies have reported high levels of inflammatory parameters in patients with HSP [7, 20-22]. The NLR is a useful marker in inflammatory diseases. Various studies have reported that high blood NLR is associated with HSP [23-25]. Lymphocyte apoptosis lead to decreased lymphocytes and increased NLR in inflammation [25]. NLR may be useful in predicting organ involvement in HSP [23, 24]. However, contradictory have been reported on the role of the NLR in HSP [25]. Further investigations are therefore needed to assess its true value.

We also observed a significant increase in serum levels of D-dimer in HSP patients. However, platelets, PT and aPTT, standard coagulation tests, were within reference ranges. These results suggest that activated coagulation is secondary to the endothelial inflammation stimulated by IgA immune deposits in patients with HSP [10]. Wang et al. [19] reported raised D-dimer level as a risk factor for renal damage in patients with HSP. Our multivariate logistic regression analysis did not showed an association between raised D-dimer level and HSP. However, our patient group included all HSP patients with and without renal involvement. The number of patients with renal involvement was low and no multivariate logistic regression analysis could be performed in this group.

Recent studies have showed that IgA autoantibodies, which are cross-reactive with endothelial cells, are present in patients with HSP [7]. Only a few studies to date have investigated parameters that may show endothelial cell damage $[3,6,10,26]$. These studies have frequently investigated Factor XIII and von Willebrand factor as markers of endothelial damage [3]. One previous study reported high von Willebrand antigen and low Factor XIII levels in patients with HSP [3, 6]. Söylemezoglu et al. [6] reported significantly increased von Willebrand factor during the acute phase of HSP and that this correlated well with CRP in the active phase, suggesting that this maybe a good indicator of vascular inflammation and endothelial damage.

The present study investigated endocan, a marker of epithelial cell damage, in patients with HSP. Endocan is associated with endothelial dysfunction [13]. Interaction between endocan and adhesion molecules causes transport of leukocytes to regions of inflammation and subsequent endothelial dysfunction [14]. High levels of endocan have been showed in the rheumatological diseases, including Behcet's disease, systemic lupus, and systemic sclerosis [13-15]. Balta et al. [13] observed significantly higher serum endocan levels in patients with Behçet's disease. CRP, ESR and disease activity correlated positively with endocan in these patients [13].

In our study, endocan levels were similar in the patients with HSP and the controls. We observed no correlation between endocan and other laboratory parameters. However, positive correlation was determined between APTT and endocan. No relation was determined between endocan and clinical findings.

HDL-C levels in our study were lower in patients with HSP than in the control group, but no correlation was determined with endocan. HDL exhibits anti-inflammatory, antithrombotic, and antioxidant effects. It also protects against atherosclerosis and endothelial dysfunction [14].

There are some limitations of our study. First, it is the small sample size. This may explain why no difference was determined between endocan levels in the two groups. Second, most of the HSP patients in our study were mild cases. Lastly, Factor XIII and von Willebrand Factor could not be determined due to our financial limitations.

In conclusion, endocan may be a useful predictor of endothelial dysfunction in patients with HSP. However, our results do not provide supportive evidence for an association between endocan and HSP. To the best of our knowledge, this is the first study to investigate endocan in children with HSP. Further studies of endocan involving a larger sample population are now needed. This will help clarify the possible role of endocan in the pathogenesis of HSP.

Acknowledgment: This study received partial financial support from the Haseki Training and Research Hospital. 
Author contributions: Concept Nilgun Selcuk Duru (NSD), Kamil Sahin (KS), Ala Ustyol (AU); Design NSD, Murat Elevli (ME), AU; Supervision NSD, ME; Data collection NSD, KS, Cihan Coskun (CC), Macit Koldas (MK); Analysis NSD, MK, CC; Literature search NSD, AU, KS; Writing NSD; Critical Review NSD, ME, MK, KS.

Conflict of interest: The authors have no conflict of interest.

\section{References}

1. Yang YH, Tsai IJ, Chang CJ, Chuang YH, Hsu HY, Chiang BL. The interaction between circulating complement proteins and cutaneous microvascular endothelial cells in the development of childhood Henoch-Schönlein purpura. PLoS One 2015;10:e0120411.

2. Heineke MH, Ballering AV, Jamin A, Ben Mkaddem S, Monteiro RC, Van Egmond M. New insights in the pathogenesis of immunoglobulin a vasculitis (Henoch-Schönlein purpura). Autoimmun Rev 2017;16:1246-53.

3. De Mattia D, Penza R, Giordano P, Del Vecchio GC, Aceto G, Altomare $\mathrm{M}$, et al. Von Willebrand factor and factor XIII in children with Henoch-Schonlein purpura. Pediatr Nephrol 1995;9:603-5.

4. ButbulAviel Y, Dafna L, Pilar G, Brik R. Endothelial function in children with a history of henochschonleinpurpura. Pediatr Rheumatol Online J 2017;15:3.

5. Brendel-Müller K, Hahn A, Schneppenheim R, Santer R. Laboratory signs of activated coagulation are common in HenochSchönlein purpura. Pediatr Nephrol 2001;16:1084-8.

6. Söylemezoglu O, Sultan N, Gursel T, Buyan N, Hasanoglu E. Circulating adhesion molecules ICAM-1, E-selectin, and von Willebrand factor in Henoch-Schonlein purpura. Arch Dis Child 1996;75:507-11.

7. Hong J, Yang HR. Laboratory markers indicating gastrointestinal involvement of henoch-schönlein purpura in children. Pediatr Gastroenterol Hepatol Nutr 2015;18:39-47.

8. Fessatou S, Nicolaidou P, Gourgiotis D, Georgouli H, Douros $\mathrm{K}$, Moustaki M, et al. Endothelin 1 levels in relation to clinical presentation and outcome of Henoch Schonlein purpura. BMC Pediatr 2008;8:33.

9. Reakatanan W, Kadegasem P, Chunharas A, Tapaneya-Olarn W, Treepongkaruna S, Sirachainan N. High D-dimer Level in Henoch-Schönlein purpura with pancreatitis. Pancreas 2016;45:e4-5.

10. Del Vecchio GC, Penza R, Altomare M, Piacente L, Aceto G, Lassandro G, et al. Cytokine pattern and endothelium damage markers in Henoch-Schönlein purpura. Immunopharmacol Immunotoxicol 2008;30:623-9.

11. Yang J, Yang Q, Yu S, Zhang X. Endocan: a new marker for cancer and a target for cancer therapy. Biomed Rep 2015;3:279-83.
12. Seo K, Kitazawa T, Yoshino Y, Koga I, Ota Y. Characteristics of serum endocan levels in infection. PLoS One 2015;10:e0123358.

13. Balta I, Balta S, Koryurek OM, Demirkol S, Mikhailidis DP, Celik T, et al. Serum endocan levels as a marker of disease activity in patients with Behcet disease. J Am Acad Dermatol 2014;70:291-6.

14. Icli A, Cure E, Cure MC, Uslu AU, Balta S, Mikhailidis DP, et al. Endocan levels and subclinical atherosclerosis in patients with systemic lupus erythematosus. Angiology 2016;67:749-55.

15. Bălănescu P, Lădaru A, Bălănescu E, Voiosu T, Băicuş C, Dan GA. Endocan, novel potential biomarker for systemic sclerosis: results of a pilot study. Clin Lab Anal 2016;30:368-73.

16. Topaloglu R, Sungur A, Baskin E, Besbas N, Saatci U, Bakkaloglu A. Vascular endothelial growth factor in Henoch-Schonlein purpura. J Rheumatol 2001;28:2269-73.

17. Ozen S, Pistorio A, lusan SM, Bakkaloglu A, Herlin T, Brik R, et al. EULAR/PRINTO/PRES criteria for Henoch-Schonlein purpura, childhood polyarteritis nodosa, childhood Wegener granulomatosis and childhood Takayasu arteritis: Ankara 2008. Part II: final classification criteria. Ann Rheum Dis 2010;69:798-806.

18. Yu HH, Liu PH, Yang YH, Lee JH, Wang LC, Chen WJ, et al. Chemokine MCP1/CCL2 and RANTES/CCL5 gene polymorphisms influence Henoch-Schönlein purpura susceptibility and severity. J Formos Med Assoc 2015;114:347-52.

19. Wang X, Zhu Y, Gao L, Wei S, Zhen Y, Ma Q. Henoch-Schönlein purpura with joint involvement: analysis of 71 cases. Pediatr Rheumatol Online J 2016;14:20.

20. Teng X, Wang Y, Lin N, Sun M, Wu J. Evaluation of serum procalcitonin and $\mathrm{C}$-reactive protein levels as biomarkers of Henoch-Schönlein purpura in pediatric patients. Clin Rheumatol 2016;35:667-71.

21. Cohen N, Mimouni FB, Friedel N, Amarilyo G. Predictors of hospital length of stay in pediatric Henoch-Schönlein purpura. Rheumatol Int 2015;35:1561-4.

22. Purevdorj N, Mu Y, Gu Y, Zheng F, Wang R, Yu J, et al. Clinical significance of the serum biomarker index detection in children with Henoch-Schonlein purpura. Clin Biochem 2018;52:167-70.

23. Makay B, Gücenmez ÖA, Duman M, Ünsal E. Response to: mean platelet volume and neutrophil-to-lymphocyte ratio in patients with Henoch-Schonlein purpura. Rheumatol Int 2014;34:1337.

24. Park CH, Han DS, Jeong JY, Eun CS, Yoo KS, Jeon YC, et al. The optimal cut-off value of neutrophil-to-lymphocyte ratio for predicting prognosis in adult patients with Henoch-Schönlein purpura. PLoS One 2016;11:e0153238.

25. Gayret OB, Erol M, Nacaroglu HT. The relationship of neutrophillymphocyte ratio and platelet-lymphocyte ratio with gastrointestinal bleeding in Henoch-Schonlein purpura. Iran J Pediatr 2016;26:e8191.

26. Besbas N, Erbay A, Saatçi U, Ozdemir S, Bakkaloglu A, Ozen $S$, et al. Thrombomodulin, tissue plasminogen activator and plasminogen activator inhibitor-1 in Henoch-Schönlein purpura. Clin Exp Rheumatol 1998;16:95-8. 